\title{
MASTL is essential for anaphase entry of proliferating primordial germ cells and establishment of female germ cells in mice
}

\author{
Sanjiv Risal ${ }^{1,6}$, Jingjing Zhang ${ }^{1,6}$, Deepak Adhikari ${ }^{2}$, Xiaoman Liu $^{3}$, Jingchen Shao ${ }^{1}$, Mengwen Hu ${ }^{1}$, \\ Kiran Busayavalasa ${ }^{1}$, Zhaowei Tu${ }^{1}$, Zijiang $\mathrm{Chen}^{3}$, Philipp Kaldis ${ }^{4,5}$, Kui Liu ${ }^{1,3}$ \\ ${ }^{1}$ Department of Chemistry and Molecular Biology, University of Gothenburg, Gothenburg, Sweden; ${ }^{2}$ Monash Biomedicine \\ Discovery Institute, Department of Anatomy and Developmental Biology, Monash University, Melbourne, Victoria, Australia; \\ ${ }^{3}$ The Key Laboratory of Reproductive Endocrinology (Shandong University), Ministry of Education, Jinan, China; ${ }^{4}$ Institute of \\ Molecular and Cell Biology (IMCB), A*STAR (Agency for Science, Technology and Research), Singapore, Republic of \\ Singapore; ${ }^{5}$ Department of Biochemistry, National University of Singapore (NUS), Singapore, Republic of Singapore
}

In mammals, primordial germ cells (PGCs) are the embryonic cell population that serve as germ cell precursors in both females and males. During mouse embryonic development, the majority of PGCs are arrested at the G2 phase when they migrate into the hindgut at 7.75-8.75 dpc (days post coitum). It is after $9.5 \mathrm{dpc}$ that the PGCs undergo proliferation with a doubling time of $12.6 \mathrm{~h}$. The molecular mechanisms underlying PGC proliferation are however not well studied. In this work. Here we studied how MASTL (microtubule-associated serine/threonine kinase-like)/Greatwall kinase regulates the rapid proliferation of PGCs. We generated a mouse model where we specifically deleted Mastl in PGCs and found a significant loss of PGCs before the onset of meiosis in female PGCs. We further revealed that the deletion of Mastl in PGCs did not prevent mitotic entry, but led to a failure of the cells to proceed beyond metaphase-like stage, indicating that MASTL-mediated molecular events are indispensable for anaphase entry in PGCs. These mitotic defects further led to the death of Mastl-null PGCs by 12.5 dpc. Moreover, the defect in mitotic progression observed in the Mastl-null PGCs was rescued by simultaneous deletion of Ppp2r1a ( $\alpha$ subunit of PP2A). Thus, our results demonstrate that MASTL, PP2A, and therefore regulated phosphatase activity have a fundamental role in establishing female germ cell population in gonads by controlling PGC proliferation during embryogenesis.

Keywords: anaphase; cell cycle; mitosis; MASTL; PP2A; primordial germ cells

Cell Discovery (2017) 3, 16052; doi:10.1038/celldisc.2016.52; published online 7 February 2017

\section{Introduction}

Primordial germ cells (PGCs) are embryonic cells that serve as progenitors of female and male gametes, and eventually differentiate into oocyte and sperm $[1,2]$. In mice, the founders of PGCs originate from pluripotent proximal epiblast cells at 6.0-6.5 dpc (days

\footnotetext{
${ }^{6}$ These authors contributed equally to this work. Correspondence: S Risal

Tel: +46317866585; Fax: +46317863910

E-mail: sanjiv.risal@gu.se

or P Kaldis

Tel: $+6565869854 ;$ Fax: +6567791117

E-mail:kaldis@imcb.a-star.edu.sg

Received 18 September 2016; accepted 12 December 2016
}

post coitum) [3]. After receiving bone morphogenetic protein (BMP) signals from the extraembryonic ectoderm, these founder cells are identifiable as PGCs at $7.25 \mathrm{dpc}$ and expression of Dppa3 (developmental pluripotency associated 3; also known as Pgc7 or Stella) marks the establishment of PGCs [4]. They begin to migrate through the developing hindgut and the mesentery, and eventually colonize the gonads at $10.5 \mathrm{dpc}[5,6]$. In mice, PGCs in the migratory phase from 7.75 to $8.75 \mathrm{dpc}$ are arrested at the $\mathrm{G} 2$ phase [7] and they proliferate rapidly from 9.5 to $12.5 \mathrm{dpc}$ with a doubling time of $12.6 \mathrm{~h}[2,8]$. Mouse PGCs increase their numbers from 9.5 to $12.5 \mathrm{dpc}$ by 50 -fold because of this rapid proliferation [8]. By $13.5 \mathrm{dpc}$, PGCs in female mouse embryos undergo a mitotic-meiotic 
transition and give rise to female germ cells [9, 10]. In male mice, PGCs undergo mitotic arrest at G0/G1 after $13.5 \mathrm{dpc}$ and meiosis starts only after birth, around post-natal day (PD) $10[11,12]$. However, the molecular mechanisms regulating the cell cycle of proliferating PGCs between 9.5-12.5 dpc have not been investigated.

The mammalian cell cycle is driven by sequential activation of different types of cyclin-dependent kinases (CDKs) [13, 14], and genetic studies in mice have shown that Cdk1 is the most important $\mathrm{Cdk}$ for entry and progression through mitosis [15, 16]. However, an increase in the activity of $\mathrm{Cdk} 1$ alone is not sufficient for faithful mitotic progression [17] and a parallel suppression of phosphatase activity is equally crucial, as shown in Xenopus egg extracts and Drosophila melanogaster [18, 19]. Studies in human cell lines, mouse embryonic fibroblasts (MEFs), and D. melanogaster demonstrated that the activation of the Greatwall kinase (GWL) or its mammalian orthologue MASTL (microtubule-associated serine/ threonine kinase-like) is essential for G2-M phase transition and mitotic progression [20-22]. In Xenopus egg extracts, it has been shown that activated GWL phosphorylates endosulfine $\alpha$ (ENSA) and cAMP-regulated phosphoprotein 19 (ARPP19), and converts them into potent inhibitors of PP2A (protein phosphatase 2A). Thus, phosphorylated ENSA/ARPP19 can bind to PP2A-B55 (PP2A with its regulatory subunit B55) and inhibit PP2A activity, which occurs at the same time when Cdk1 activity peaks [23-26]. These regulatory events ensure the maximal phosphorylation of $\mathrm{Cdk} 1$ substrates to complete mitosis as shown in Xenopus egg extracts [24].

In the current study, we investigated the functions of MASTL in PGC proliferation by using a tamoxifeninducible Dppa3-CreMER (Cre fused with murine estrogen receptor) mouse model to delete Mastl from PGCs. We found that the deletion of Mastl from proliferating PGCs resulted in a significant loss of PGCs by 12.5 dpc. Mastl-null PGCs did not proceed to anaphase, indicating that MASTL is indispensable for anaphase entry in PGCs. This mitotic defect further led to the activation of the DNA damage response pathway and thus the majority of Mastl-null PGCs underwent apoptotic cell death by $12.5 \mathrm{dpc}$. Moreover, the anaphase entry defect in Mastl-null PGCs was rescued by the simultaneous deletion of Ppp2r1a ( $\alpha$ subunit of PP2A). Thus, our results demonstrate that phosphatase regulatory unit MASTL-PP2A has a fundamental role in mediating mouse PGC proliferation.

\section{Results}

Dppa3-CreMER specifically deletes Mastl in PGCs

We used a tamoxifen-inducible Dppa3-CreMER mouse model to induce Cre activity specifically in PGCs [4]. We crossed Dppa3-CreMER mice with $m T / m G$ reporter mice [27], and observed that in the embryo, Cre-expressing PGCs under the control of the Dppa3 promoter exhibit a switch from red fluorescence (mT, membrane-targeted Tomato) to green fluorescence $(\mathrm{mG}$, membrane-targeted green fluorescence protein, GFP). Injection of tamoxifen to pregnant females at $9.5 \mathrm{dpc}$ caused the expression of $\mathrm{mG}$ specifically in female PGCs at $13.5 \mathrm{dpc}$. The specific Cre activity in PGCs was further confirmed by double immunofluorescence analysis of female embryonic gonads at $13.5 \mathrm{dpc}$ using both anti-mouse Vasa homolog (MVH, a germ cell marker) and anti-GFP antibodies (Supplementary Figure S1C and F, arrows). We confirmed that the GFP-positive cells are indeed PGCs because these cells exclusively expressed both GFP (Supplementary Figure S1A and D, arrows) and MVH (Supplementary Figure S1B and E, arrows). However, GFP expression was absent in MVHpositive cells of vehicle-treated Dppa3-CreMER; $m T / m G$ female embryonic gonads at $13.5 \mathrm{dpc}$ (Supplementary Figure S1G-I, arrows).

We crossed Mastl ${ }^{\text {loxPlloxP}}[28]$ female mice with Mastl loxPlloxP Dppa3-CreMER; $m$ T/mG male mice and tamoxifen was injected in pregnant females at $9.5 \mathrm{dpc}$ (Supplementary Figure S1J). The resulting Mastl loxPlloxP, Dppa3-CreMER; $m$ T/mG embryos were referred to as PGC-Mastl ${ }^{-1-}$. As a control, we crossed $m T / m G$ female mice with Dppa3-CreMER; $m T / m G$ male mice, and the resulting Dppa3-CreMER; $m T / m G$ embryos were referred to as PGC-Mastl ${ }^{+++}$.

To validate the deletion of Mastl in $11.5 \mathrm{dpc}$ female gonads, we used GFP to sort $\mathrm{Mastl}^{++}$and $\mathrm{Mastl}^{-{ }^{-}}$ PGCs by fluorescence-activated cell sorting (FACS) from $11.5 \mathrm{dpc}$ female gonads. RT-PCR indicated that the Mastl mRNA expression was almost completely absent in $\mathrm{Mastl}^{-1-}$ PGCs (Figure 1a). These results indicated that Dppa3-CreMER led to efficient deletion of Mastl by tamoxifen injection at $9.5 \mathrm{dpc}$ (Supplementary Figure S2).

\section{Ablation of Mastl in PGCs results in germ cell loss in the gonads}

The PGC-Mastl ${ }^{-1}$ female and male mice had significantly smaller ovaries and testes, respectively compared with PGC-Mastl ${ }^{++}$mice at PD 45 (Figure 1b). The deletion of Mastl in PGCs resulted in 
a

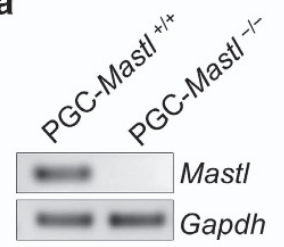

$9.5 \mathrm{dpc} \rightarrow 11.5 \mathrm{dpc}$

GFP+PGCs
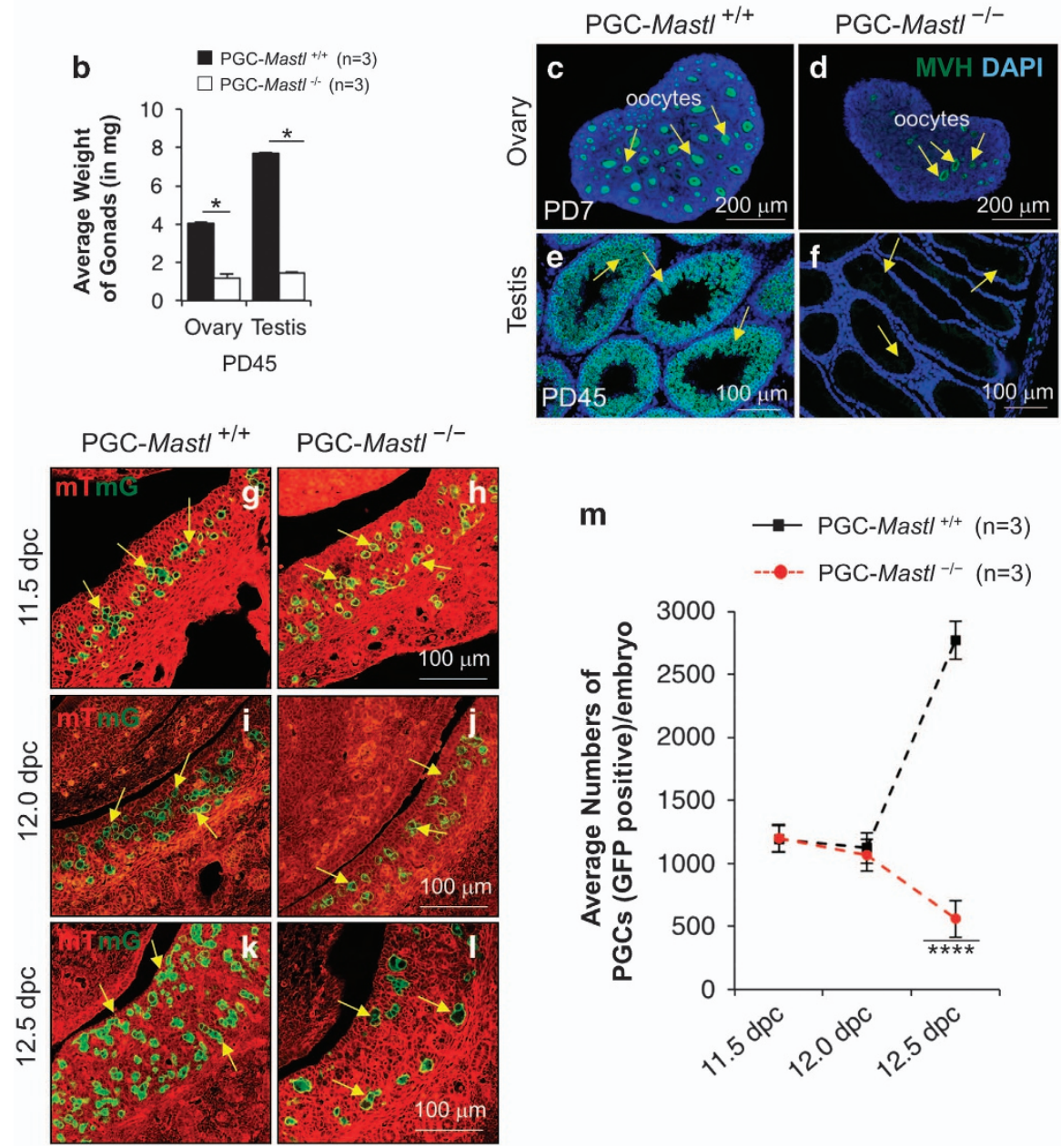

Figure 1 Deletion of Mastl in PGCs leads to the depletion of germ cells in both males and female gonads. (a) RT-PCR showing

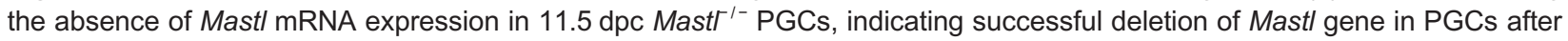
tamoxifen injection at $9.5 \mathrm{dpc}$. Gapdh was used as an internal control. (b) Average weight (in mg) of adult PGC-Mast ${ }^{+/+}$and PGC-Mast $\Gamma^{1-}$ testes and ovaries at PD45. PGC-Mast $\Gamma^{1-}$ testes and ovaries were significantly smaller than PGC-Mast $I^{+/+}$testes and ovaries. ' $n$ ' is the number of female and male gonads analyzed for each genotype. (c, d) Staining for MVH (green) showing that by PD7 only a few follicles remained in the PGC-Mast ${ }^{\prime-}$ ovary (d, arrows) compared to the PGC-Mast ${ }^{+/+}$ovary where a normal pool of follicles was seen (c, arrows). Scale bars $=200 \mu \mathrm{m}$. (e, f) Staining for MVH (green) showing that PGC-Mast $\Gamma^{1-}$ seminiferous tubules in adult testes were deficient in germ cells (f, arrows) compared to PGC-Mast ${ }^{+/+}$testes (e, arrows) at PD45. Scale bars $=100 \mu \mathrm{m}$. DNA was stained with DAPI. (g-l) Morphological analysis of female embryonic gonads showing that the deletion of Mastl in PGCs at $9.5 \mathrm{dpc}$ caused the depletion of PGCs by $12.5 \mathrm{dpc}$. The morphology of $11.5 \mathrm{dpc}$ (g, h, arrows), $12.0 \mathrm{dpc}$ (i, j, arrows), and $12.5 \mathrm{dpc}$ (k, I, arrows) GFP-positive Mastl ${ }^{+/}$and Mast $\Gamma^{\prime-}$ PGCs. Scale bar $=100 \mu \mathrm{m}$. (m) Quantification of the average numbers of GFP-positive Mast $\digamma^{+/}$PGCs (black dotted line) and Mast $\Gamma^{1-}$ PGCs (red dotted line) per female embryo at 11.5, 12.0 and $12.5 \mathrm{dpc}$. At 11.5 and $12.0 \mathrm{dpc}$, no significant changes in the number of PGCs were seen in PGC-Mast $\Gamma^{++}$and PGC-Mast $\Gamma^{1-}$ female embryonic gonads. At $12.5 \mathrm{dpc}$, however, the PGC-Mast $\Gamma^{1-}$ female embryonic gonads displayed a significant reduction in PGCs compared to PGC-Mast ${ }^{1+}$ female embryonic gonads. ' $n$ ' is the number of female embryos analyzed for each genotype. The experiments were repeated three times each, for each time point gonads from one embryo of each genotype were used, and representative images are shown. The data are means \pm s.e.m., ${ }^{\star} P<0.05$ and ${ }^{* * * *} P<0.0001$.

Cell Discovery | www.nature.com/celldisc 
a nearly complete loss of germ cells in both males and females in adulthood as shown by MVH staining for germ cells in ovaries and testes at PD7 and PD45, respectively (Figure 1c-f, arrows). In subsequent experiments, we focused our studies on the development of female PGCs.

We found that the average numbers of Mastl $^{{ }^{-1}}$ and $\mathrm{Mast}^{+++}$PGCs were indistinguishable in $11.5 \mathrm{dpc}$ (Figure $1 \mathrm{~g}$ and $\mathrm{h}$, arrows and $\mathrm{m}$ ) and in $12.0 \mathrm{dpc}$ female gonads (Figure $1 \mathrm{i}$ and $\mathrm{j}$, arrows and $\mathrm{m}$ ). However, analysis of $12.5 \mathrm{dpc}$ female gonads revealed a significantly lower number of $\mathrm{Mastl}^{-1-}$ PGCs compared with $\mathrm{Mast}^{+++}$PGCs (Figure 1k and 1, arrows and m). These results indicated that by $12.5 \mathrm{dpc}$ the majority of Mastl $^{-1-}$ PGCs had been depleted.

\section{MASTL deficiency in PGCs causes deregulation of cell cycle}

To understand the cell cycle distribution of $\mathrm{Mast}^{+/+}$ and Mast $^{-1-}$ PGCs, we carried out propidium iodide (PI)-based FACS cell cycle analysis of PGCs in female gonads. Notably, our FACS data at $11.5 \mathrm{dpc}$ showed an accumulation of $58 \%$ of the Mastl $^{-1-}$ PGCs with a $4 n$ DNA content (Figure 2a) compared with an accumulation of $39 \%$ of the $\mathrm{Mastl}^{+/+}$PGCs with a $4 \mathrm{n}$ DNA content (Figure 2b). When we examined cell proliferation by staining for Ki67 at $12.5 \mathrm{dpc}$, Mastl $^{-1-}$ PGCs displayed lower levels of Ki67 staining compared to $\mathrm{Mast}^{+++}$PGCs (Figure 2c-j, arrows and $\mathrm{k}$ ).

Tissue sections of ovary (Figure $3 \mathrm{a}-\mathrm{c}$ ) and the metaphase spread of PGCs (Figure $3 \mathrm{~d}-\mathrm{f}$ ) at $11.5 \mathrm{dpc}$ displayed condensed chromosomes, indicating both $\mathrm{Mastl}^{+++}$and $\mathrm{Mastl}^{-1-}$ PGCs entered mitosis. We also found that more Mast $^{\prime-}$ PGCs were positive for phosphorylated histone $\mathrm{H} 3$ at Ser10 (pHH3 S10, a mitotic marker) than $\mathrm{Mast}^{+++}$PGCs (Supplementary Figure S3a-h, arrows and i). Thus, our results suggest that deletion of Mastl from PGCs at $9.5 \mathrm{dpc}$ did not prevent mitotic entry, which differs from what was observed in Xenopus egg extracts.

\section{Mastl deletion prevents anaphase entry in PGCs}

To study mitotic progression in $\mathrm{Mastl}^{{ }^{-1-}}$ PGCs, we took an in vitro approach and cultured $12.0 \mathrm{dpc}$ female embryonic gonads in nocodazole-containing medium. Nocodazole is a compound that arrests the cells at prometaphase [29] due to its ability to destabilize microtubules, but upon release from nocodazole, cells synchronously enter metaphase and anaphase. We found that a 4-h treatment of $12.0 \mathrm{dpc}$ female gonads with $0.2 \mu \mathrm{M}$ nocodazole was sufficient to cause prometaphase arrest in wild-type PGCs (Supplementary Figure S4a, arrows and f). At 20 and 40 min after nocodazole release, the PGCs were still in prometaphase (Supplementary Figure S4b and c, arrows). However, at $60 \mathrm{~min}$ after release from nocodazole, $28.7 \%$ of the PGCs were in metaphase (Supplementary Figure S4d, arrows and g) and 13\% were in anaphase (Supplementary Figure S4e, arrows and g).

We then arrested $12.0 \mathrm{dpc} \mathrm{Mast}^{+/+}$and $\mathrm{Mastl}^{\text {I- }^{-}}$ PGCs in prometaphase for $4 \mathrm{~h}$ by nocodazole. Immediately after release from nocodazole arrest, both $\mathrm{Mastl}^{++}$and $\mathrm{Mastl}^{\prime-}$ PGCs were found in the prometaphase state (Figure $3 \mathrm{~g}$ and $\mathrm{k}$, arrows). When $12.0 \mathrm{dpc}$ embryonic gonads were cultured with nocodazole followed by MG132 treatment to arrest PGCs at metaphase, we found that $47 \%$ of Mastl $^{-1-}$ PGCs were arrested at metaphase-like stage (Supplementary Figure S4i and j), which was comparable to $48 \%$ of control $\mathrm{Mastl}^{+++}$PGCs at this stage (Supplementary Figure S4h and j). However, $60 \mathrm{~min}$ after release from nocodazole, $26.5 \%$ of the Mastl $^{+++}$PGCs were in metaphase-like stage (Figure 3h, arrows and o) and $18.5 \%$ of the $\mathrm{Mastl}^{+++}$PGCs were in anaphase (Figure 3i, arrows and p). In contrast, 23.2\% of the $\mathrm{Mastl}^{-1-}$ PGCs reached metaphase-like stage by $60 \mathrm{~min}$ after release from nocodazole (Figure 31, arrows and o), but none of these mutant PGCs proceeded to anaphase (Figure 3p). The Mast $^{{ }^{\prime-}}$ PGCs exhibited abnormal cellular morphology with fragmented DNA (Figure 3m, arrow). Even at $90 \mathrm{~min}$ after nocodazole release, the $\mathrm{Mastl}^{{ }^{-1}}$ PGCs did not enter anaphase (Figure 3n), while the $\mathrm{Mastl}^{+++}$ PGCs normally entered anaphase (Figure 3j), indicating that $\mathrm{Mastl}^{-1-}$ PGCs failed to enter anaphase and their DNA became fragmented, leading to a mitotic catastrophe.

We also observed that Mast $^{1-}$ PGCs formed micronuclei (Supplementary Figure S5a and b, arrows and c), binucleate and giant cells (Supplementary Figure S5d, arrowheads), indicating chromosome segregation defects. Staining for phosphorylated ATM (pATM, Ser 1981) (Supplementary Figure S6a and b, arrows), Chk2 (Supplementary Figure S6c and d, arrows and e), and phosphorylated $\mathrm{H} 2 \mathrm{AX}(\gamma \mathrm{H} 2 \mathrm{AX})$ (Supplementary Figure S6f and g, arrows and j) in $12.5 \mathrm{dpc} \mathrm{Mastl}^{-1-}$ PGCs indicated that DNA damage was increased in the absence of Mastl in PGCs. DNA damage caused a significant accumulation of p53 (Supplementary Figure S6h and i, arrows and k) and the downstream target of p53, PUMA (p53 upregulated modulator of apoptosis), in the nuleus of $\mathrm{Mastl}^{\text {I- }^{-}}$ 

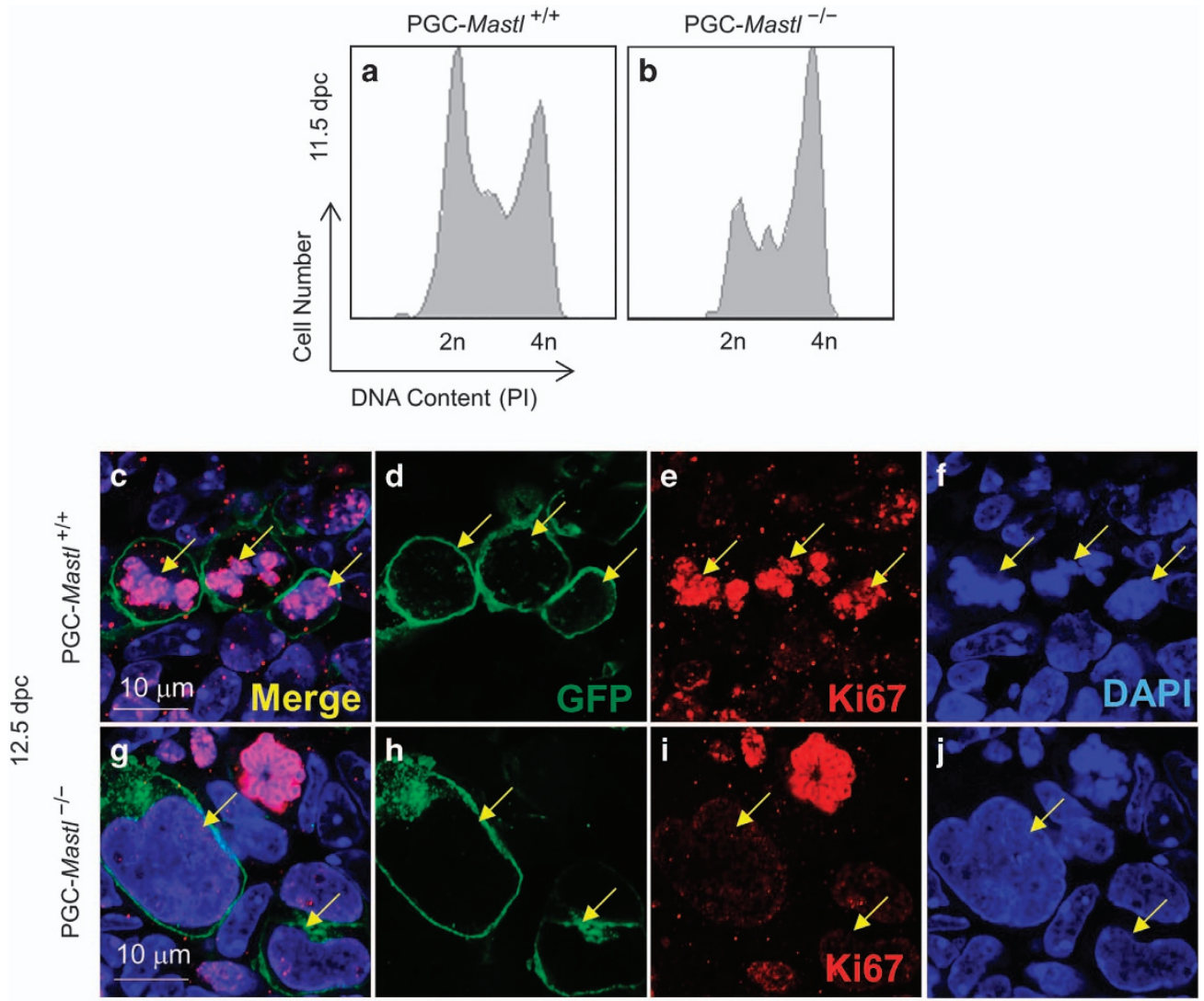

k

Ki67 high

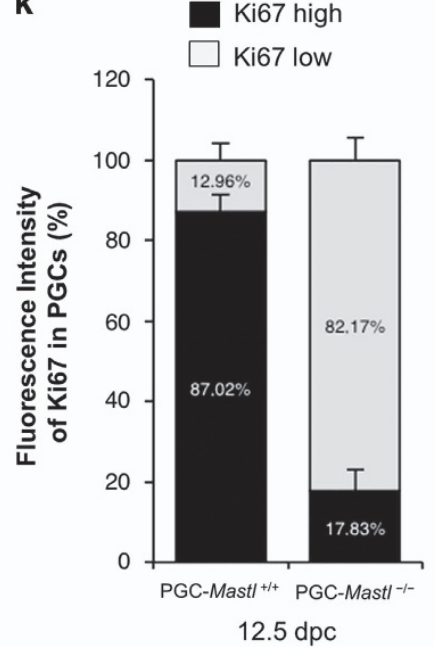

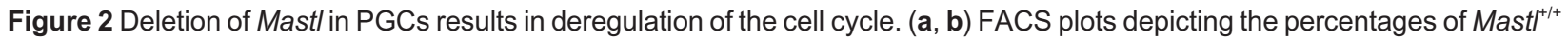
and Mast $^{\prime-}$ PGCs with 2n (37.9 versus 30.3\%) and 4n DNA content (39.4 versus $\left.58.2 \%\right)$ at $11.5 \mathrm{dpc}$. The vertical axis represents the cell number and the horizontal axis represents the DNA content (PI staining). (c-j) Staining for the cell proliferation marker Ki67 (red) in Mast ${ }^{\prime-}$ PGCs (g, arrows) and Mastl ${ }^{++}$PGCs (c, arrows). PGCs were co-stained with a GFP antibody (green) that recognizes $m G$ (d, h, arrows). The DNA was stained with DAPI (blue) (f, j, arrows). Scale bars $=10 \mu m$. (k) Quantification of mean fluorescence intensity of Ki67 in $\mathrm{Mast}^{+/+}$and $\mathrm{Mast}^{\prime-}{ }^{--} \mathrm{PGCs}$ (in \%). PGCs with high Ki67 fluorescence intensity are shown in black, and PGCs with low Ki67 fluorescence intensity are shown in grey. The Data are means \pm s.e.m. The experiments were repeated three times each, for each time point, gonads from one embryo of each genotype were used, and representative images are shown. 
PGC-Mastl ${ }^{+/+}$

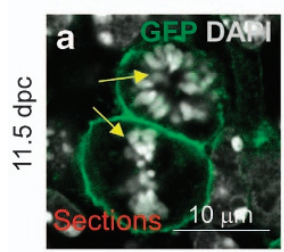

C

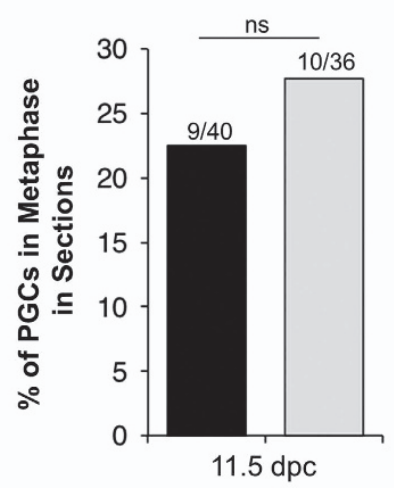

PGC-Mast/ ${ }^{-1-}$

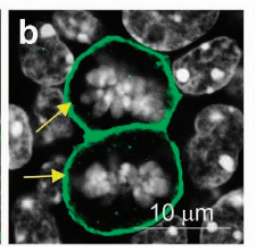

- PGC-Mastl ${ }^{+/+}$

$\square$ PGC-Mastl ${ }^{-/-}$

$11.5 \mathrm{dpc}$

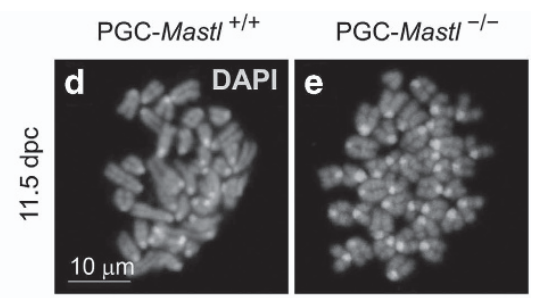

$4 \mathrm{~h}$ nocodazole treatment

f

- PGC-Mastl ${ }^{+++}$

$\square$ PGC-Mastl $^{-1-}$

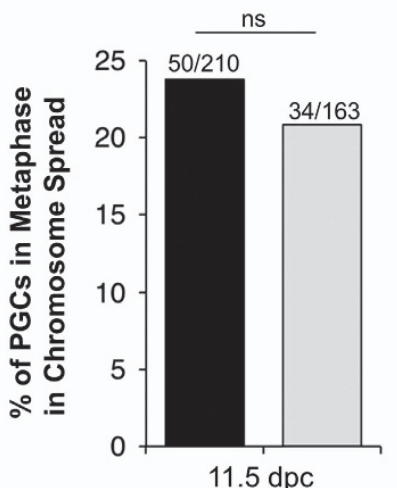

$11.5 \mathrm{dpc}$

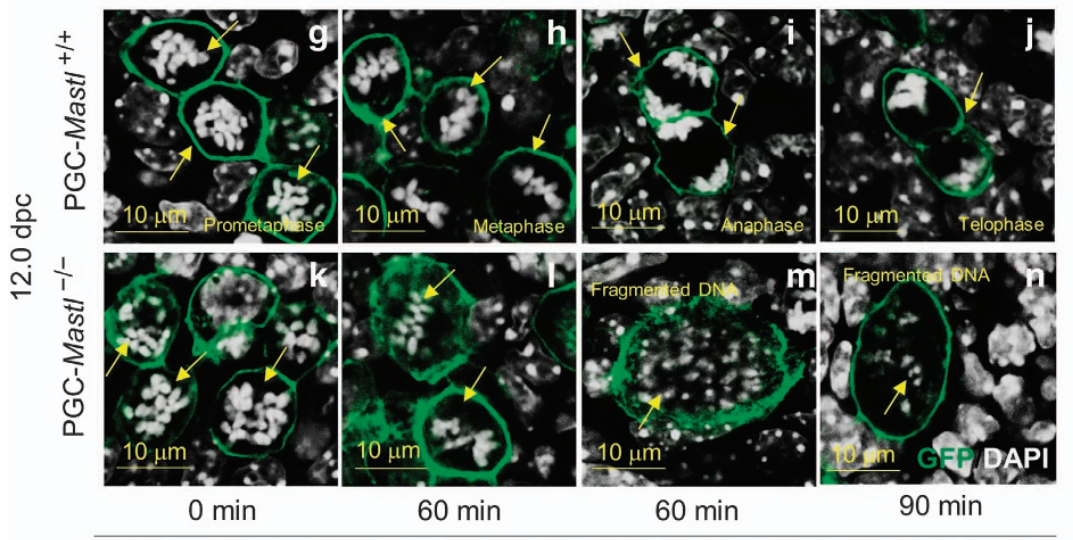

Nocodazole release

o

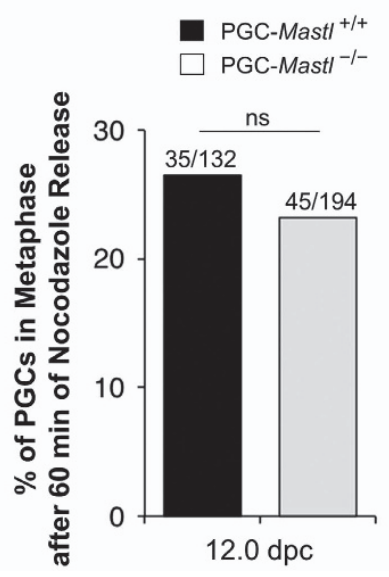

$\mathbf{p}$
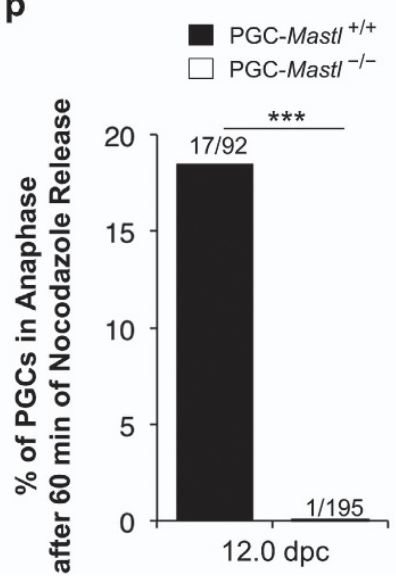
PGCs (Supplementary Figure S61 and m, arrows and p). As a response to the upregulation of p53 in Mastl $^{-1-}$ PGCs, apoptotic pathways were activated since we observed increased staining for activated caspase-3 (Supplementary Figure S6n and o, arrows and q). Thus, the depletion of $12.5 \mathrm{dpc} \mathrm{Mastl}^{-1-}$ PGCs was associated with the activation of a caspase-3dependent apoptotic pathway as a result of the metaphase arrest.

The deletion of PP2A rescues the loss of $\mathrm{Mastl}^{-1-}$ PGCs

In Xenopus egg extracts, it has been shown that MASTL-mediated suppression of PP2A is essential for mitotic entry and progression [23, 24]. To investigate the contribution of PP2A activation in PGC development, we generated double-mutant mice lacking both Ppp2rla (the PP2A $\alpha$-subunit) and Mastl in PGCs (these embryos were referred to as PGC-Mast ${ }^{\prime-}$; Ppp2rla ${ }^{-1-}$ ).

The simultaneous deletion of Mastl and Ppp2r1a appeared to rescue the ovarian phenotype observed in Mastl $^{-1-}$ PGCs and resulted in normal-looking populations of follicles at PD7 in PGC-Mastl ${ }^{-1-} ;{\text { Ppp } 2 r 1 a^{-/}}^{-1}$ double knockout ovaries (Figure $4 \mathrm{a}-\mathrm{c}$ and $\mathrm{e}-\mathrm{g}$, arrows, whole ovary in inset). We further confirmed that PGCs in $\mathrm{Mastl}^{-1-}$; Ppp2r1a ${ }^{-1-}$ female embryonic gonads developed and survived normally at $12.5 \mathrm{dpc}$ (Figure $4 \mathrm{i}-\mathrm{k}$, arrows), and there were no abnormal nuclear structures or micronuclei (Figure $4 \mathrm{~m}$ and o, arrows) such as those seen in $\mathrm{Mastl}^{-l-}$ PGCs at $12.5 \mathrm{dpc}$ (Figure 4n). Additionally, the PGC-Ppp2rla $a^{-1-}$ ovaries and PGC-Ppp2rla ${ }^{-/-}$embryonic gonads appreared normal, when Ppp2rla was deleted from 9.5 dpc PGCs (Figure 4d,h,1 and p, arrows).

When we cultured $12.0 \mathrm{dpc} \mathrm{Mastl}^{-1-}$; Ppp2r1a ${ }^{-1-}$ female embryonic gonads with $0.2 \mu \mathrm{M}$ nocodazole for
$4 \mathrm{~h}$ and released these gonads from prometaphase arrest for $60 \mathrm{~min}, 10 \%$ of the $\mathrm{Mast}^{l^{-1}}$; Ppp2rla $\mathrm{P}^{-1-}$ PGCs entered anaphase, compared to the $\mathrm{Mastl}^{-1-}$ PGCs (less than 1\%) (Figure 4q-s, arrow and Figure 4t and $\mathrm{u}$ ). Collectively, these results indicate that the loss of PP2A in $\mathrm{Mastl}^{-{ }^{-}}$PGCs partially rescued the mitotic exit defect.

\section{The absence of Cdk1 in PGCs causes mitosis arrest}

Because phosphorylation of MASTL depends on Cdk1 activity in Xenopus egg extracts [30], we hypothesized that deletion of $C d k 1$ from PGCs would phenocopy the Mastl deficiency in PGCs. We crossed $C d k 1^{\text {loxPlloxP }}$ females [16] with $C d k 1^{\text {loxPlloxP }}$; Dppa3-CreMER; $m T / m G$ males and analyzed PGC development in the female embryonic gonads at $11.5 \mathrm{dpc}, 12.5 \mathrm{dpc}$, and $13.5 \mathrm{dpc}$. We found that at $12.5 \mathrm{dpc}$, PGCs that were deficient in $\mathrm{Cdk} 1$ displayed significantly lower survival rate than $\mathrm{Cdkl}^{+/+}$PGCs (Supplementary Figure S7a-d, arrowheads and g). By $13.5 \mathrm{dpc}$, $C d k 1^{-1-}$ PGCs were almost completely absent from the gonads (Supplementary Figure S7e-f, arrowheads and g). Thus, our data indicate that $C d k 1^{-1-}$ PGCs stop proliferating after $11.5 \mathrm{dpc}$, which results in severe depletion of PGCs by $13.5 \mathrm{dpc}$ in PGC-Cdk1 ${ }^{-1-}$ gonads. Moreover, lower levels of Ki67 staining indicated that $C d k 1^{-1-}$ PGCs are not proliferating (Supplementary Figure S8a and b, arrowheads) and unable to progress through mitosis as indicated by the absence of $\mathrm{pHH} 3$ S10 immunostaining (Supplementary Figure S8c-e, arrowheads). These results were further supported by cell cycle analysis through FACS indicating that $C d k 1^{-1-}$ PGCs were arrested at the G1 phase at $12.5 \mathrm{dpc}$ (Supplementary Figure S8f and g). The failure of $C d k 1^{-l-}$ PGCs to proceed into mitosis was accompanied with the upregulation of the apoptotic pathway

Figure $3 \mathrm{Mast}^{1-}$ PGCs fail to transit to anaphase. (a, b) Morphological analysis of female embryonic gonads showing metaphase-like structures with condensed chromosomes stained with DAPI in GFP-positive Mast ${ }^{+/}$and Mast $\Gamma^{1-}$ PGCs (arrows). (c) Quantification of the number of GFP-positive $\mathrm{Mast}^{+/+}$and $\mathrm{Mast}^{\digamma^{\prime-}}$ PGCs displaying condensed chromosomes in sections. (d, e) Chromosome spreads of

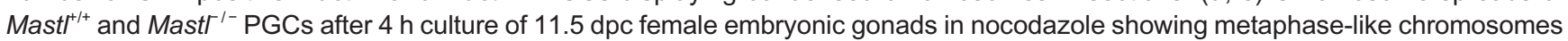
in $\mathrm{Mast}^{1-}$ and Mastl/+ PGCs. Chromosomes were stained with DAPI. (f) Quantification of metaphase-like spreads per total number of cells at $11.5 \mathrm{dpc}$. The experiments were repeated three times each and representative images are shown. (g-n) Morphological analysis of female embryonic gonads demonstrating that both $12.0 \mathrm{dpc} \mathrm{Mastl^{+/+ }}$ and $\mathrm{Mast}^{/{ }^{\prime-}} \mathrm{PGCs}$ were arrested in prometaphase after $4 \mathrm{~h}$ culture in nocodazole (g, k, arrows). $12.0 \mathrm{dpc} \mathrm{MastI^{1+ }}$ and Mast $\Gamma^{1-}$ PGCs entered metaphase-like stage 60 min after nocodazole release (h, I, arrows). Mast $\digamma^{-1-}$ PGCs failed to enter anaphase ( $\mathbf{m}$, arrow) and displayed fragmented DNA structure, whereas Mast ${ }^{+/+}$PGCs progressed normally to anaphase (I, arrows) 60 min after nocodazole release. Mast ${ }^{1-}$ PGCs could not enter anaphase 90 min after nocodazole release $\left(\mathbf{n}\right.$, arrow), whereas Mast ${ }^{+/+}$PGCs had entered telophase (j, arrow). DNA was stained with DAPI. Scale

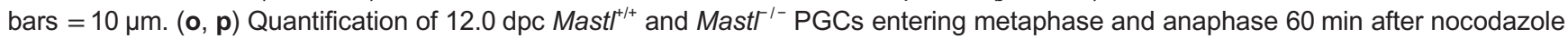
release (in \%). ' $n$ ' represents the total number of GFP-positive PGCs analyzed in three embryos of each genotype. The experiments were repeated three times each and representative images are shown. ${ }^{* *} P<0.001$. 

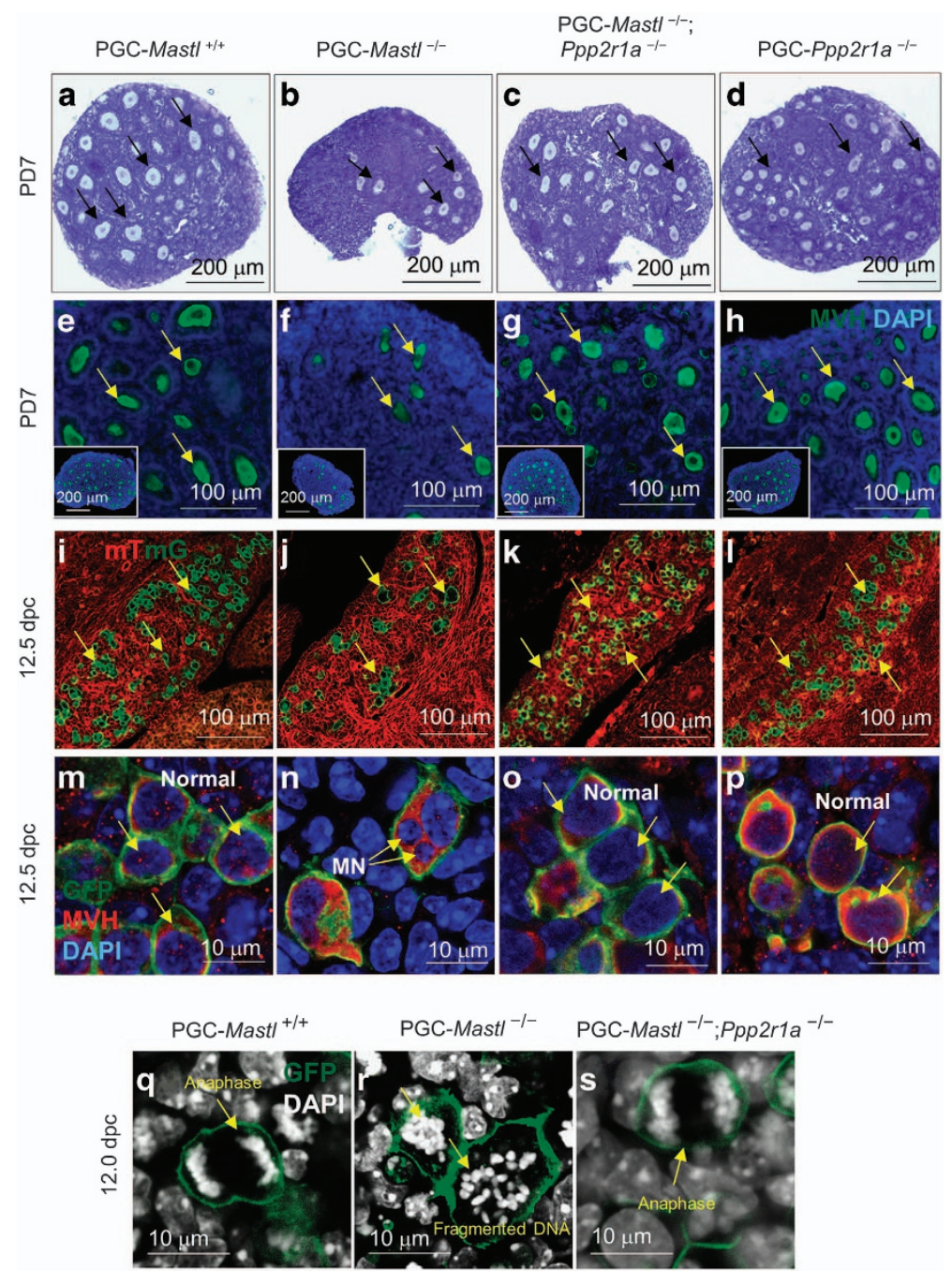

$\mathbf{t}$

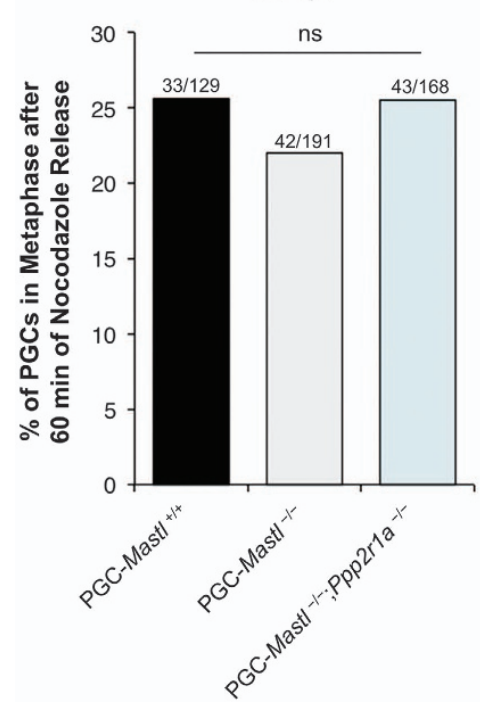

$\mathbf{u}$

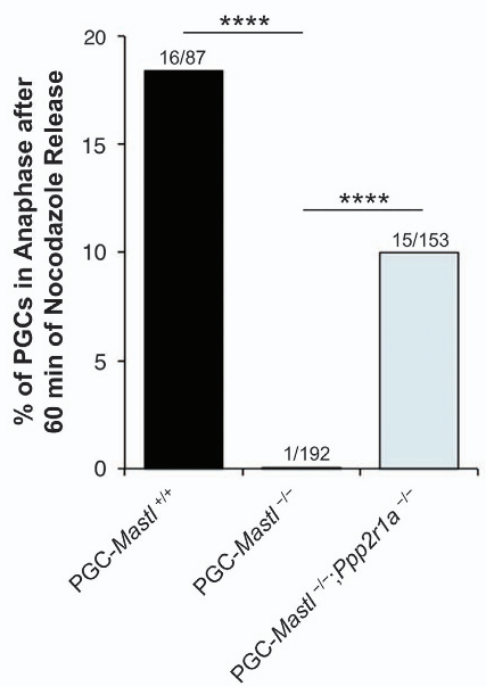


at $12.5 \mathrm{dpc}$ (Supplementary Figure S8h and i, arrowheads and $\mathrm{j}$ ), which led to the elimination of defective PGCs. Together, our data show that the phenotype observed in $C d k 1^{-1-}$ PGCs was not identical to that of Mastl $^{-1-}$ PGCs, suggesting that Cdk1 has additional functions in PGCs besides activating MASTL.

\section{Discussion}

In the current study, we uncovered that MASTL has an essential role in PGC proliferation during embryogenesis, which is important for the establishment of oocyte pool in the mouse ovary. In the absence of Mastl, PGCs fail to exit mitosis, causing mitotic catastrophe and subsequent apoptotic cell death during embryonic development. Thus, Mastl is an indispensable gene for PGC development (as summarized in Figure 5a and b). Moreover, we found that simultaneous deletion of Ppp2rla from PGCs partially rescued the defect in the mitotic exit caused by Mastl deletion, genetically demonstrating that MASTL-mediated suppression of PP2A activity is crucial for normal mitotic exit of proliferating PGCs.

MASTL has different roles during mitotic progression in different cell types, as shown by the diverse phenotypes reported in different model systems. In MEFs, loss of Mastl results in prometaphase arrest [20] and chromosome segregation defects [31]. In contrast, in D. melanogaster, Gwl or Mastl mutation generates chromosome condensation defects and a delay in mitotic entry and progression [22]. The RNAi knockdown of the MASTL gene in human cell lines causes G2 arrest and cytokinesis defects [21]. Hence, the Mastl $^{-1-}$ PGCs provide a unique model to study how
MASTL is involved in the dynamic control of the cell cycle in these specialized cell types, which are the precursors of female germ cells.

By using genetic approaches, we demonstrated that progression to prometaphase and metaphase in mouse PGCs is independent of MASTL and MASTLmediated PP2A suppression. This is in sharp contrast to the phenotypes of Mastl-deficient MEFs, D. melanogaster, and human cell lines [20-22]. We further demonstrated that the failure to proceed beyond metaphase was likely caused by aberrantly elevated PP2A activity since simultaneous deletion of MASTL and PP2A led anaphase progression in PGCs. The failure in mitotic progression in $\mathrm{Mast}^{--}$PGCs led to the accumulation of DNA damage and the defective PGCs were quickly eliminated by apoptosis before the PGCs could differentiate into germ cells. Our results suggest that MASTL might safeguard DNA integrity during mitosis in rapidly dividing mouse PGCs.

PGCs are specified after receiving bone morphogenetic protein (BMP) signals from the extraembryonic tissues and they are among the first lineages to be established in embryos [32]. In addition, PGCs are unique embryonic cells that divide rapidly with doubling times as little as $12.6 \mathrm{~h}$, thus expanding their population from $\sim 200$ cells at $9.5 \mathrm{dpc}$ to $\sim 10000$ cells at $12.5 \mathrm{dpc}$ in mice [8]. Therefore, PGCs have a unique mitotic profile compared to most of the other mitotic cell types. However, there are only a limited number of studies on the mechanisms underlying the proliferation of PGCs. The loss of Pin1 (peptidyl-prolyl isomerase) results in fewer germ cells in both male and female mice, and Pin1-null PGCs show proliferation defects due to a prolonged cell cycle and this leads to a reduced

Figure 4 Deletion of Ppp2r1a in Mastl ${ }^{-/-}$PGCs leads to anaphase entry. (a-d) Comparable ovarian morphologies in PGC-Mastl ${ }^{+/+}$and PGC-Mastl ${ }^{-1-}$; Ppp2r1a ${ }^{-/-}$female mice at PD7, indicating that the simultaneous deletion of Mastl and Ppp2r1a in PGCs (a, c, arrows) rescued the phenotype observed in PGC-Mast $\Gamma^{\prime-}$ ovaries (b, arrows). Scale bar $=200 \mu \mathrm{m}$. (e-h) Staining for MVH (green) indicated that the simultaneous deletion of Mastl and Ppp2r1a in PGCs led to similar germ cell pools in PGC-Mastl $I^{++}$and PGC-Mastl/ ; Ppp2r1a $^{-/-}$ ovaries (e, g, arrows, a whole ovary is shown in the inset) compared with PGC-Mast ${ }^{1-}$ ovaries (f, arrows) at PD7. Scale bars $=100 \mu \mathrm{m}$. (i-I) Morphological analysis of $12.5 \mathrm{dpc}$ female embryonic gonads showed comparable numbers of PGCs in PGC-Mast ${ }^{++}$and PGC-Mast/ ${ }^{-1-}$; Ppp2r1a ${ }^{-/-}$female embryonic gonads (i, k, arrows) compared to fewer PGCs in PGC-Mast ${ }^{1-}$ gonads (j, arrows). Scale bars $=100 \mu \mathrm{m}$. (m-p) Staining for MVH (red) and GFP (green) indicating that the simultaneous deletion of Mastl and Ppp2r1a in PGCs

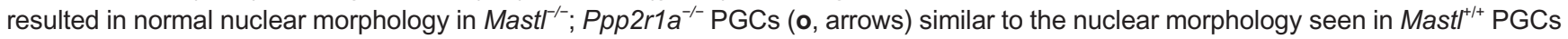

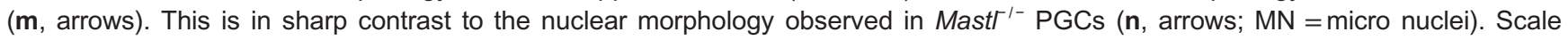
bar $=10 \mu \mathrm{m}$. (q-s) Morphological analysis of the simultaneous deletion of Mastl and Ppp2r1a in PGCs, which partially rescued the metaphase-anaphase transition defect after release from nocodazole arrest. After release from nocodazole, $12.0 \mathrm{dpc} \mathrm{Mast}^{I^{--}} ; \mathrm{Ppp}^{\mathrm{r}} \mathrm{ra}^{-{ }^{--}}$ PGCs entered anaphase normally after $60 \mathrm{~min}$, similar to Mast ${ }^{+/+}$PGCs (q, s, arrow). However, Mast $\Gamma^{1-}$ PGCs failed to enter anaphase and displayed fragmented DNA structures at $60 \mathrm{~min}$ after nocodazole release (r, arrows). (t, u) Quantification of $12.0 \mathrm{dpc}$ Mast $I^{1+}$,

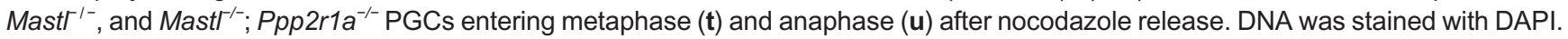
Scale bars $=10 \mu \mathrm{m}$. The experiments were repeated three times each, for each time point gonads from one embryo of each genotype were used, and representative images are shown. ${ }^{* * *} P<0.0001$. 
10

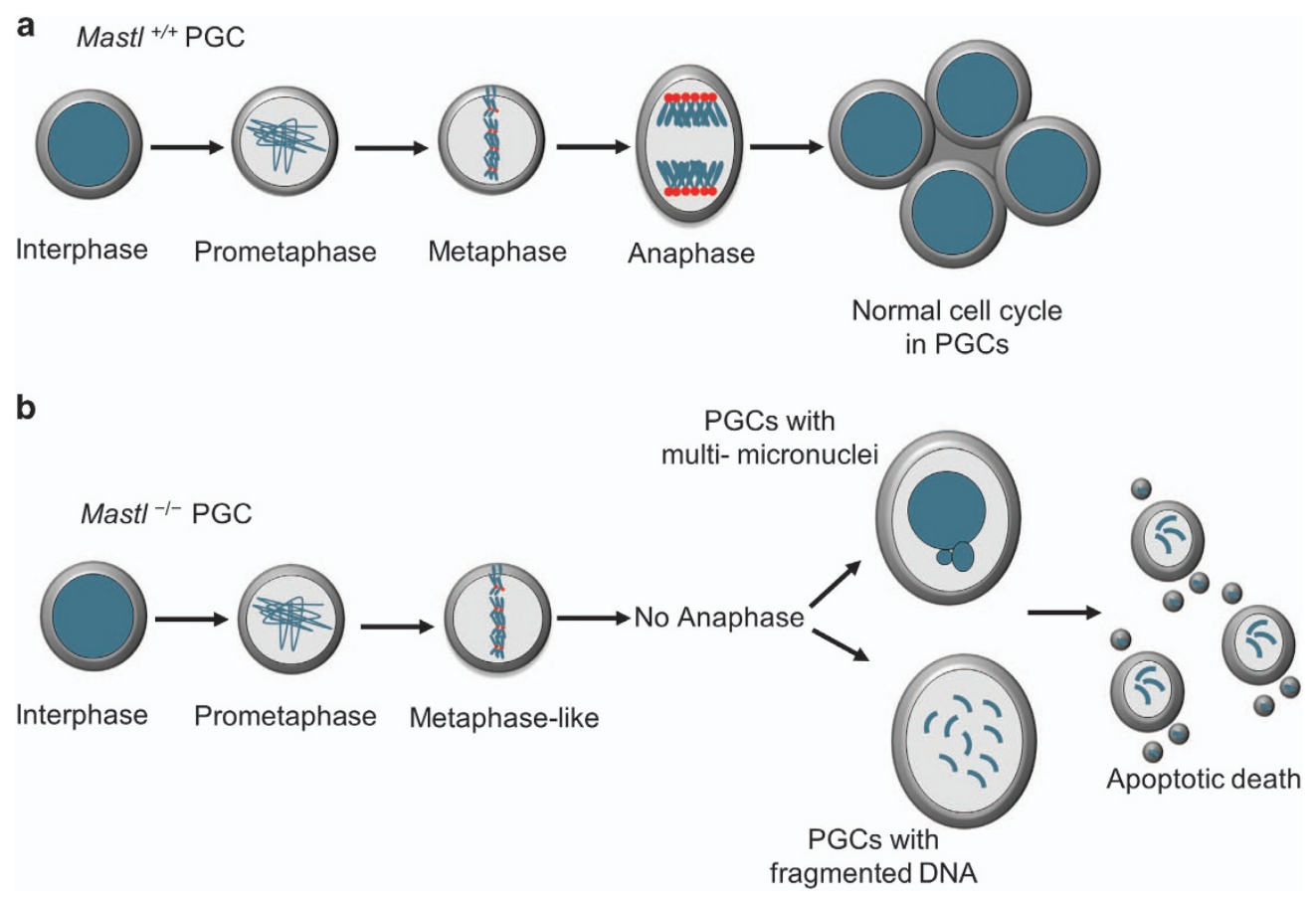

Figure 5 Model depicting cell cycle defect in Mastl-null PGCs. (a, b) In Mast ${ }^{+/+}$PGCs, the cell cycle progression is normal as shown in a. The loss of Mastl in PGCs causes defects in anaphase entry and abnormal Mast $\Gamma^{\prime-}$ PGCs are eliminated by apoptosis (b).

number of germ cells in the adult animal [33]. Additionally, Pten (phosphatase and tensin homolog deleted from chromosome 10) has been shown to be involved in cell cycle control of PGCs and loss of Pten causes the differentiation of PGCs into malignant cells and testicular teratoma in male mice [34]. Recently, it has been shown that Prmt5 (protein arginine methyltransferase 5) is important for maintaining the cell cycle in PGCs in mice. The PGC-specific deletion of Prmt5 causes cell cycle exit in PGCs and thus prevents the developmental switch that occurs between 9.5 and $10.5 \mathrm{dpc}$ as marked by the expression of $M v h$ [35]. We believe that our findings are valuable for studying cell cycle regulation in PGCs in the context of the reported mechanisms of PGC proliferation.

In conclusion, our study demonstrated that Mastl is an indispensable gene involved in the mitotic progression in PGCs, which prevents mitotic catastrophe and the apoptotic cell death of PGCs. Mastl-mediated suppression of PP2A is essential to proceed into anaphase, as shown by the simultaneous deletion of Mastl and Ppp2rla in PGCs compared with the deletion of Mastl alone. Therefore, this study expands our understanding of how the cell cycle is regulated during the rapid proliferation of PGCs in developing embryonic gonad.

\section{Materials and Methods}

\section{Mice}

$m T / m G$ (007576) and PPP2rla $a^{\text {loxPlloxP }}$ (017475) mice were purchased from the Jackson Laboratory (Bar Harbor, ME, USA). The Dppa3-CreMER (RBRC05385) mice were kindly provided by Mitinori Saitou of the Institute for Integrated CellMaterial Sciences, Kyoto University. The generation of the Mastl $^{\text {loxPlloxP}}$ [28] and Cdk1 $1^{\text {loxPlloxP}}$ [16] mice has been described previously. These Mastl ${ }^{\text {loxPlloxP}}$, PPP2rla ${ }^{\text {loxPlloxP}}$, and $C d k 1^{\text {loxPlloxP}}$ mice were crossed with Dppa3-CreMER, $m T / m G$ mice to introduce the inducible Cre and $m T / m G$ reporter system into the mice. After multiple rounds of crossing, we obtained homozygous Mastl ${ }^{\text {loxPlloxP}} ;$ Dppa3-CreMER; $m$ T/mG mice (designated as PGC-Mast $t^{-1-}$ mice), Mastl ${ }^{\text {loxPloxP }}$; PPP2rl $a^{\text {loxPlloxP }}$; Dppa3CreMER; $m$ T/mG mice (designated as PGC-Mastl ${ }^{-1-} ;$ PPP2rla ${ }^{--}$mice), Cdk1 loxPlloxP; Dppa3-CreMER; $m T / m G$ mice (designated as PGC-Cdk1 $1^{-1-}$ mice), and Dppa3-CreMER; $m T / m G$ mice (designated as PGC-Mastl ${ }^{+++}$mice and PGC-Cdkl $I^{+/+}$mice). The obtained experimental mice were of mixed background (129S1/SvlmJ and C57BL/6).

All mice were housed under controlled environmental conditions with free access to water and food. Illumination was on between 6 a.m. and 6 p.m. Experimental protocols were approved by the regional ethical committee of the University of Gothenburg, Sweden.

Female Mastl ${ }^{\text {loxPlloxP }}$ mice were mated with male Mast ${ }^{\text {loxPlloxP}}$; Dppa3-CreMER; $m T / m G$ mice, and at noon on the day when a vaginal plug was observed was scored as $0.5 \mathrm{dpc}$. To delete 
Mastl from developing PGCs, we administered $2 \mathrm{mg}$ tamoxifen (Sigma-Aldrich, St Louis, MO, USA, T5648) intraperitoneally to pregnant female mice at $9.5 \mathrm{dpc}$. The injected pregnant female mice were killed to harvest PGC-Mastl ${ }^{-1}$ female embryonic gonads at $11.5 \mathrm{dpc}, 12.0 \mathrm{dpc}$, and $12.5 \mathrm{dpc}$. A similar strategy was followed to generate PGC-Mastl ${ }^{+/+}$, PGC-Mastl ${ }^{-1-}$;

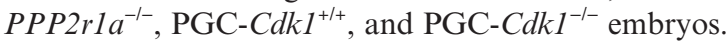

Embryos younger than $13.5 \mathrm{dpc}$ were sexed by PCR for the $\mathrm{X}$ chromosome-specific gene Jaridlc and the Y chromosomespecific gene Jaridld with the primers 5'-CTG AAG CTT TTG GCT TTG AG-3' and 5'-CCA CTG CCA AAT TCT TTG G-3', respectively. The PCR products were resolved in $3 \%$ agarose gels, and the male embryos showed a $331 \mathrm{bp}$ band for Jarid1c and a 302 bp band for Jarid1d, whereas female embryos showed a single $331 \mathrm{bp}$ band for Jaridlc.

\section{Preparation of tamoxifen}

Tamoxifen (Sigma, T5648) was dissolved in 100\% ethanol to make a stock solution of $100 \mathrm{mg} \mathrm{ml}^{-1}$ that was then diluted in corn oil (Sigma, C8267) prior to injection to make it $20 \mathrm{mg} \mathrm{ml}^{-1}$. The plugged females were injected with a single dose of $2 \mathrm{mg}$ tamoxifen to induce excision of the floxed Mastl allele. The scheme for the injection of tamoxifen was optimized for the maximum survival of embryos and efficiency of Mastl deletion. A similar strategy was followed to induce excision of the floxed PPP2rla and the floxed Cdk1 alleles.

\section{Preparation of PGCs for FACS}

Female Mastl ${ }^{\text {loxPlloxP }}$ mice were crossed with Mastl loxPlloxP $^{\text {; }}$; Dppa3-CreMER; $\quad m$ T/mG males to obtain MastloxPlloxP; Dppa3-CreMER; $m T / m G$ embryos. Tamoxifen was injected into $9.5 \mathrm{dpc}$ pregnant Mastl $^{\text {loxPlloxP }}$ female mice, and PGC-Mastl ${ }^{+/+}$ and PGC-Mastl ${ }^{-1-}$ gonads were harvested from 11.5 and $12.5 \mathrm{dpc}$ female embryos. The genotyping of Mastl ${ }^{\text {loxPlloxP}}$; Dppa3-CreMER; $m$ T/mG embryos was done by visualizing whole gonads under a microscope (SteREO, Discovery. V8, Zeiss, Munich, Germany) for green fluorescence. The expression of GFP marked the Cre recombination and deletion of the Mastl gene in PGCs. Gonads were cleaned of nongonadal tissues and digested for $30 \mathrm{~min}$ at $37^{\circ} \mathrm{C}$ with $1: 10$ collagenase (400 $\mathrm{U} \mathrm{ml}^{-1}$ collagenase IV stock (Gibco, Carlsbad, CA, USA) that was diluted $1: 10$ in $1 \times$ PBS). After $30 \mathrm{~min}$ of incubation, the collagenase was aspirated carefully without disturbing the gonads. The gonadal cells were dispersed in prewarmed sterile $1 \times$ PBS by pipetting up and down several times. The GFP-positive $\mathrm{Mastl}^{+++}$and $\mathrm{Mastl}^{-1-}$ PGCs were sorted on a BD FACS ArialI cytometer (BD Biosciences, San Jose, CA, USA). The isolated/sorted GFP-positive PGCs were checked under a microscope, which showed a $99 \%$ pure population of PGCs. A similar strategy was followed for PGC-Cdk1 ${ }^{-1-}$ and PGC-Cdk1 $1^{+/+}$embryos.

\section{$R T-P C R$}

A total of $3000 \mathrm{Mastl}^{+/+}$and $\mathrm{Mastl}^{-1-}$ PGCs sorted by FACS were used to prepare total RNA with the RNeasy Mini kit (Qiagen, Hilden, Germany) according to the manufacturer's instructions. Oligo (dT)-primed cDNA was synthesized using the iScript cDNA synthesis kit (BioRad, Hercules, CA, USA).
Real time PCR for Mastl was performed using the primers 5'GGA GTA TCT TAT TGG TGG AGA-3' and 5'AGC ATA TTG TCC GGT TTC AA-3' on a CFX-Connect Real-Time system (Bio-Rad) using iTaq Universal SYBR Green PCR master mix (Bio-Rad). The reaction was performed in triplicate. Gapdh was used as the internal control. The PCR products were run on a $3 \%$ agarose gel with ethidium bromide.

\section{Cell cycle analysis}

To determine the cell cycle distribution of $\mathrm{Mastl}^{+/+}$and Mast $^{-1-}$ PGCs, Mastl loxPlloxP females were crossed with Mastl $^{\text {loxPlloxP }}$; Dppa3-CreMER; $m T / m G$ males to obtain Mastl $^{\text {loxPlloxP }}$; Dppa3-CreMER; $m T / m G$ embryos. Tamoxifen was injected into $9.5 \mathrm{dpc}$ pregnant Mast $^{\text {loxPlloxP }}$ female mice, and PGCs were isolated from $11.5 \mathrm{dpc}$ PGC-Mastl ${ }^{++}$and PGC-Mast ${ }^{-1-}$ embryos. Briefly, the embryonic gonads were dispersed into single cells by incubating with $1: 10$ collagenase for $30 \mathrm{~min}$ at $37^{\circ} \mathrm{C}$. The individual GFP-positive $\mathrm{Mast}^{+/+}$and Mast $^{1-}$ PGCs were sorted on a BD FACS AriaII cytometer (BD Biosciences). A total of 500-1000 PGCs were used for PI staining for $2 \mathrm{~h}$ using Vindelov's reagent [36]. This reagent contained $100 \mathrm{ml}$ Tris-buffered saline $\mathrm{pH} 7.6,1 \mathrm{mg}$ (350 units) ribonuclease A (Sigma, R-5000), $7.5 \mathrm{mg}$ PI (Sigma, P4170), and $100 \mu 1$ NP-40 (Sigma, N-3516). After PI staining, the BD FACS AriaII cytometer with FACSDiva software (BD Biosciences) was used for cell cycle analysis. A similar strategy was followed

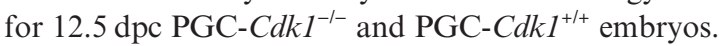

\section{Histological analysis and immunofluorescence staining}

Mastl loxPlloxP females were crossed with MastloxPlloxP; Dppa3-CreMER; $m$ T/mG males to obtain MastloxPlloxP ; Dppa3CreMER; $m T / m G$ embryos. Tamoxifen was injected into $9.5 \mathrm{dpc}$ pregnant Mastl ${ }^{\text {loxPlloxP }}$ female mice. Because tamoxifen injection compromised the natural vaginal delivery, Mastl ${ }^{\text {loxPlloxP}}$; Dppa3-CreMER; $m T / m G$ pups were delivered by Cesarean section at $19.5 \mathrm{dpc}$. Ovaries and testes were dissected from adult PGC-Mastl ${ }^{++}$and PGC-Mastl ${ }^{1-}$ females and males (fostered mice), and were fixed in $4 \%$ paraformaldehyde (Sigma) at $4{ }^{\circ} \mathrm{C}$ overnight, embedded in paraffin, sectioned, and immunostained for rabbit MVH (Abcam, Cambridge, UK, ab13840) and mouse GFP (Santa Cruz Biotechnology, Santa Cruz, CA, USA, B-2, sc-9996). A similar strategy was followed to generate PGCMastl $^{+++}$, PGC-Mastl ${ }^{-1-}$; PPP2rla ${ }^{-/-}$, PGC-Cdk1 $1^{+/+}$and PGC$C d k 1^{-1-}$ mice.

Immunofluorescence staining of embryonic sections was carried out as described previously [37]. Briefly, whole female embryos at 11.5 and $12.5 \mathrm{dpc}$ were fixed at $4{ }^{\circ} \mathrm{C}$ overnight in $4 \%$ paraformaldehyde, dehydrated, paraffin embedded, and sectioned $(8 \mu \mathrm{m}$ thick). The slides were dewaxed and rehydrated with an ethanol gradient, and antigens were retrieved by microwaving in citrate buffer $(10 \mathrm{mM}$ sodium citrate, $0.05 \%$ Tween 20, $\mathrm{pH}$ 6.0) for $10 \mathrm{~min}$. After blocking in $10 \%$ goat serum, slides were incubated with primary antibodies in $10 \%$ goat serum at $4{ }^{\circ} \mathrm{C}$ overnight. Slides were then incubated with goat secondary antibodies conjugated to Alexa 488 or Alexa 594 (Molecular Probes, Carlsbad, CA, USA), and DNA was stained with DAPI. The slides were viewed by using a Plan-Apochromat 
63 X/1.4 Oil DIC M27 objective on a laser-scanning confocal microscope (Zeiss LSM 700).

Primary antibodies against rabbit phospho-histone H3 (S10) (Cell Signal Technology, Beverly, MA, USA, 9701), rabbit Ki67 (Abcam, ab15580), mouse p-ATM (S1981) (Santa Cruz Biotechnology, 10H11.E12, sc47739), rabbit Chk2 (Abcam, ab47433), rabbit $\gamma$-H2AX (S139) (Abcam, ab2893), mouse p53 (Abcam PAb 240, ab26), rabbit PUMA (Millipore, Billerica, MA, USA, ABC158), rabbit MVH/DDX4 (Abcam, ab13840), rabbit active cleaved caspase-3 (Abcam, ab2302), mouse GFP (Santa Cruz Biotechnology, B-2, sc-9996), and rabbit GFP (Abcam, ab290) were used in this study.

For Ki67 immunofluorescence staining, images were acquired with a Zeiss LSM 700 confocal microscope. The quantification of mean fluorescence intensity in GFP-positive PGCs was performed in Image $\mathbf{J}$ [38].

\section{Chromosome spread}

Female embryonic gonads with mesonephroi were dissected from $11.5 \mathrm{dpc}$ PGC-Mastl ${ }^{+/}$and PGC-Mastl ${ }^{1-}$ embryos. The dissected embryonic gonads were cultured for $4 \mathrm{~h}$ in DMEMF12 medium (Invitrogen, Carlsbad, CA, USA) supplemented with 15\% FBS penicillin/streptomycin (Invitrogen), non-essential amino acids (Invitrogen), L-glutamine (Invitrogen), and sodium pyruvate (Invitrogen). The medium also contained $0.2 \mu \mathrm{M}$ nocodazole (Sigma) to arrest PGCs in prometaphase. After culturing for $4 \mathrm{~h}$, gonads were cleaned from non-gonadal tissues with a needle and incubated in 1:10 collagenase for $15 \mathrm{~min}$ at $37^{\circ} \mathrm{C}$. The collagenase-treated gonads were then incubated in $0.5 \% \mathrm{KCl}$ for $10 \mathrm{~min}$ and disperesed in the remaining hypotonic buffer. Freshly prepared ice-cold acetic acid: methanol $(1: 3)$ fixative was used to fix the individualized PGCs. This step was repeated one more time and the cells were dropped onto slides. DAPI was used to analyze metaphase chromosome spread on a laser-scanning confocal microscope (Zeiss LSM 700).

\section{In vitro culture of embryonic gonads}

For in vitro culture of embryonic gonads, $m T / m G$ females were crossed with Dppa3-CreMER; $m T / m G$ males to obtain Dppa3-CreMER; $m T / m G$ transgenic embryos (wild type). All the experiments were carried out at room temperature unless otherwise indicated. Female embryonic gonads with mesonephroi were dissected from $12.0 \mathrm{dpc}$ Dppa3-CreMER; $m T / m G$ embryos (wild type). The dissected embryonic gonads were cultured for $4 \mathrm{~h}$ in DMEM-F12 medium (Invitrogen) supplemented with 15\% FBS penicillin/streptomycin (Invitrogen), non-essential amino acids (Invitrogen), L-glutamine (Invitrogen), and sodium pyruvate (Invitrogen) along with $0.2 \mu \mathrm{M}$ nocodazole to arrest PGCs in prometaphase. After $4 \mathrm{~h}$ of culturing, the female gonads were washed three times with pre-warmed culture medium and further cultured without nocodazole. At $0,20,40$, and $60 \mathrm{~min}$ after release from nocodazole, 12.0 dpc Dppa3-CreMER, $m T / m G$ female gonads were fixed in $4 \%$ paraformaldehyde overnight. These fixed $12.0 \mathrm{dpc}$ female gonads were dehydrated, paraffin embedded, sectioned, and stained with DAPI to visualize the DNA. In a similar way, female gonads from $12.0 \mathrm{dpc}$ PGC-Mast ${ }^{+/+}$and PGC-Mast $T^{\prime-}$ embryos were cultured in $0.2 \mu \mathrm{M}$ nocodazole for
$4 \mathrm{~h}$. At $60 \mathrm{~min}$ after release from nocodazole, female gonads were fixed in $4 \%$ paraformaldehyde and processed as above. In these $12.0 \mathrm{dpc}$ female gonads, PGCs were already expressing the $\mathrm{mG}$ reporter (GFP). For each experiment, three or more embryonic gonads were used for culture and analysis. A similar strategy was followed for generating PGC-Mastl ${ }^{-1-} ; P P P 2 \mathrm{rla}^{-1-}$ embryonic gonads.

To validate metaphase entry in Mastl $^{-1-}$ PGCs, $12.0 \mathrm{dpc}$ embryonic gonads from PGC-Mastl ${ }^{++}$and PGC-Mastl ${ }^{1-}$ embryos were cultured in $0.2 \mu \mathrm{M}$ nocodazole for $4 \mathrm{~h}$. After nocodazole washout, then embryonic gonads were cultured in $10 \mu \mathrm{M}$ MG132 (Millipore) for $60 \mathrm{~min}$. Then female gonads were fixed in $4 \%$ paraformaldehyde and processed as above.

\section{Statistical analysis}

All experiments were repeated at least three times. The quantitative data (mean \pm s.e.m.) were analyzed by Student's $t$-test by using GraphPad Prism version 6 (GraphPad Software, La Jolla, CA, USA), and differences were considered significant when $P<0.05$.

\section{Conflict of Interest}

The authors declare no conflict of interest.

\section{Acknowledgements}

This study was supported by grants to KL from the Jane and Dan Olssons Foundation, the LUA/ALF-medel Västra Götalandsregionen, AFA Insurance, the Swedish Research Council, and the Swedish Cancer Foundation, Sweden. PK was supported by the Biomedical Research Council of A*STAR (Agency for Science, Technology and Research), Singapore. We acknowledge the Centre for Cellular Imaging at University of Gothenburg.

\section{Author contributions}

PK, KL, ZC designed the study. SR, JZ, DA, XL, JS, MH, $\mathrm{KB}, \mathrm{ZT}$ performed the experiments. DA, PK, KL, SR wrote the manuscript.

\section{References}

1 McLaren A. Primordial germ cells in the mouse. Dev Biol 2003; 262: 1-15.

2 Kurimoto K, Saitou M. Mechanism and reconstitution in vitro of germ cell development in mammals. Cold Spring Harb Symp Quant Biol 2015; 80: 147-154.

3 Durcova-Hills G, Tang F, Doody G, Tooze R, Surani MA. Reprogramming primordial germ cells into pluripotent stem cells. PLoS ONE 2008; 3: e3531.

4 Hirota T, Ohta H, Shigeta M, Niwa H, Saitou M. Drug-inducible gene recombination by the Dppa3-MER Cre MER transgene in the developmental cycle of the germ cell lineage in mice. Biol Reprod 2011; 85: 367-377. 
5 Yamaji M, Seki Y, Kurimoto K et al. Critical function of Prdm14 for the establishment of the germ cell lineage in mice. Nat Genet 2008; 40: 1016-1022.

6 Ohinata Y, Payer B, O'Carroll D et al. Blimp1 is a critical determinant of the germ cell lineage in mice. Nature 2005; 436: 207-213.

7 Seki Y, Yamaji M, Yabuta Y et al. Cellular dynamics associated with the genome-wide epigenetic reprogramming in migrating primordial germ cells in mice. Development 2007; 134: 2627-2638.

8 Kagiwada S, Kurimoto K, Hirota T, Yamaji M, Saitou M. Replication-coupled passive DNA demethylation for the erasure of genome imprints in mice. EMBO J 2013; 32: 340-353.

9 McLaren A. Germ and somatic cell lineages in the developing gonad. Mol Cell Endocrinol 2000; 163: 3-9.

10 Miles DC, van den Bergen JA, Sinclair AH. Western PS. Regulation of the female mouse germ cell cycle during entry into meiosis. Cell Cycle 2010; 9: 408-418.

11 Western PS, Miles DC, van den Bergen JA, Burton M, Sinclair AH. Dynamic regulation of mitotic arrest in fetal male germ cells. Stem Cells 2008; 26: 339-347.

12 Sung WK, Komatsu M, Jagiello GM. The kinetics of the first wave of spermatogenesis in the newborn male mouse. Gamete Res 1986; 14: 245-254.

13 Lim S, Kaldis P. Cdks, cyclins and CKIs: roles beyond cell cycle regulation. Development 2013; 140: 3079-3093.

14 Morgan DO. The Cell Cycle: Principles of Control. Oxford University Press; New Science Press: Oxford London, 2006.

15 Santamaria D, Barriere C, Cerqueira A et al. Cdk1 is sufficient to drive the mammalian cell cycle. Nature $2007 ; \mathbf{4 4 8}$ : 811-815.

16 Diril MK, Ratnacaram CK, Padmakumar VC et al. Cyclin-dependent kinase $1(\mathrm{Cdk} 1)$ is essential for cell division and suppression of DNA re-replication but not for liver regeneration. Proc Natl Acad Sci USA 2012; 109: 3826-3831.

17 Virshup DM, Kaldis P. Cell biology, enforcing the greatwall in mitosis. Science 2010; 330: 1638-1639.

18 Bollen M, Gerlich DW, Lesage B. Mitotic phosphatases: from entry guards to exit guides. Trends Cell Biol 2009; 19: 531-541.

19 Castilho PV, Williams BC, Mochida S, Zhao Y, Goldberg ML. The M phase kinase Greatwall (Gwl) promotes inactivation of PP2A/B55delta, a phosphatase directed against CDK phosphosites. Mol Biol Cell 2009; 20: 4777-4789.

20 Alvarez-Fernandez M, Sanchez-Martinez R, Sanz-Castillo B et al. Greatwall is essential to prevent mitotic collapse after nuclear envelope breakdown in mammals. Proc Natl Acad Sci USA 2013; 110: 17374-17379.

21 Burgess A, Vigneron S, Brioudes E, Labbe JC, Lorca T, Castro A. Loss of human Greatwall results in G2 arrest and multiple mitotic defects due to deregulation of the cyclin B-Cdc2/PP2A balance. Proc Natl Acad Sci USA 2010; 107 : 12564-12569.
22 Yu J, Fleming SL, Williams B et al. Greatwall kinase: a nuclear protein required for proper chromosome condensation and mitotic progression in Drosophila. $J$ Cell Biol 2004; 164: 487-492.

23 Gharbi-Ayachi A, Labbe JC, Burgess A et al. The substrate of Greatwall kinase, Arpp19, controls mitosis by inhibiting protein phosphatase 2A. Science 2010; 330: 1673-1677.

24 Mochida S, Ikeo S, Gannon J, Hunt T. Regulated activity of PP2A-B55 delta is crucial for controlling entry into and exit from mitosis in Xenopus egg extracts. EMBO J 2009; 28: 2777-2785.

25 Yu C, Ji SY, Sha QQ, Sun QY, Fan HY. CRL4-DCAF1 ubiquitin E3 ligase directs protein phosphatase 2A degradation to control oocyte meiotic maturation. Nat Commun 2015; 6: 8017.

26 Mochida S, Maslen SL, Skehel M, Hunt T. Greatwall phosphorylates an inhibitor of protein phosphatase 2A that is essential for mitosis. Science 2010; 330: 1670-1673.

27 Muzumdar MD, Tasic B, Miyamichi K, Li L, Luo L. A global double-fluorescent Cre reporter mouse. Genesis 2007; 45: 593-605.

28 Adhikari D, Diril MK, Busayavalasa K et al. Mastl is required for timely activation of $\mathrm{APC} / \mathrm{C}$ in meiosis I and Cdk1 reactivation in meiosis II. J Cell Biol 2014; 206: 843-853.

29 Matsui Y, Nakayama Y, Okamoto M, Fukumoto Y, Yamaguchi N. Enrichment of cell populations in metaphase, anaphase, and telophase by synchronization using nocodazole and blebbistatin: a novel method suitable for examining dynamic changes in proteins during mitotic progression. Eur J Cell Biol 2012; 91: 413-419.

30 Yu J, Zhao Y, Li Z, Galas S, Goldberg ML. Greatwall kinase participates in the $\mathrm{Cdc} 2$ autoregulatory loop in Xenopus egg extracts. Mol Cell 2006; 22: 83-91.

31 Diril MK, Bisteau X, Kitagawa M et al. Loss of the Greatwall kinase weakens the spindle assembly checkpoint. PLoS Genet 2016; 12: e1006310.

32 Extavour CG, Akam M. Mechanisms of germ cell specification across the metazoans: epigenesis and preformation. Development 2003; 130: 5869-5884.

33 Atchison FW, Capel B, Means AR. Pin1 regulates the timing of mammalian primordial germ cell proliferation. Development 2003; 130: 3579-3586.

34 Kimura T, Suzuki A, Fujita Y et al. Conditional loss of PTEN leads to testicular teratoma and enhances embryonic germ cell production. Development 2003; 130: 1691-1700.

35 Li Z, Yu J, Hosohama L et al. The $\mathrm{Sm}$ protein methyltransferase PRMT5 is not required for primordial germ cell specification in mice. EMBO J 2015; 34: 748-758.

36 Vindelov LL. Flow microfluorometric analysis of nuclear DNA in cells from solid tumors and cell suspensions. A new method for rapid isolation and straining of nuclei. Virchows Arch B, Cell Pathol 1977; 24: 227-242. 
$37 \mathrm{Hu}$ YC, Nicholls PK, Soh YQ et al. Licensing of primordial germ cells for gametogenesis depends on genital ridge signaling. PLoS Genet 2015; 11: e1005019.

38 Kim S, Gunesdogan U, Zylicz JJ et al. PRMT5 protects genomic integrity during global DNA demethylation in primordial germ cells and preimplantation embryos. Mol Cell 2014; 56: 564-579.

(Supplementary Information is linked to the online version of the paper on the Cell Discovery website.) (c) (i) This work is licensed under a Creative Commons Attribution 4.0 International License. The images or other third party material in this article are included in the article's Creative Commons license, unless indicated otherwise in the credit line; if the material is not included under the Creative Commons license, users will need to obtain permission from the license holder to reproduce the material. To view a copy of this license, visit http://creativecommons.org/licenses/by/4.0/

(C) The Author(s) 2017 